\title{
Rancang Bangun Turbin Reaksi pada Sungai Taman Kota 2 dengan Model Aliran Vortex
}

\author{
Chairil Insani 1,a), Andi Maulana ${ }^{2, b)}$, Ochtafian Wahyu Irawan ${ }^{3, c)}$ \\ ${ }^{1,2,3}$ Program Studi Teknik Mesin ITI , \\ J1. Raya Puspiptek Serpong, Tangerang Selatan-Banten, Indonesia, 15320 \\ a) chairilinsani1999@gmail.com, ${ }^{\text {b) }}$ maulanaandi6770@gmail.com, ${ }^{c}$ z.ochtafian@gmail.com
}

\begin{abstract}
Abstrak
Listrik merupakan kebutuhan yang harus ada sekarang ini, penggunaanya selalu mengalami penikatan. Listrik sebagian besar berasal dari pembangkit berbasis energi fosil seperti PLTU. Oleh karenanya, dibuatlah solusi dengan membuat turbin air vortex untuk menghasilkan energi listrik. Memanfaatkan aliran sungai yang head jatuh airnya kecil, air akan masuk menuju penampang. Aliran akan membentuk vortex karena bentuk dari penampang dan adanya draft tube membuat sisi bawah penampang memiliki tekanan lebih rendah. Pada turbin vortex ini telah dirancang menggunakan generator AC 150 watt magnet permanen. Dengan penampang $60 \times 55 \times 150 \mathrm{~cm}$, draft tube $9,6 \mathrm{~mm}$ dan sudu turbin $30 \times$ $50 \mathrm{~cm}$ berbahan alumunium. Pada kerangka digunakan plat strip $3 \times 3,5 \mathrm{~cm}$ yang di roll. Agar bisa menahan benturan air di sudu, digunakan poros diameter luar $22 \mathrm{~mm}$ diameter dalam $16 \mathrm{~mm}$ dengan bahan pipa baja, dan umur nominal bantalan 10274 jam. Putaran yang dihasilkan diteruskan dengan puli diameter $30 \mathrm{~mm}, 180 \mathrm{~mm}$ dan dengan jenis sabuk $v$ belt material JIS K 6323 A 34.
\end{abstract}

Kata kunci: generator, listrik, turbin air, vortex

\begin{abstract}
Electricity is a necessity that must exist today, its use is always subject to binding. Most of the electricity comes from fossil energy-based power plants such as PLTU. Therefore, a solution was made by making a vortex water turbine to produce electrical energy. Utilizing a river flow with a small head, the air will enter the cross section. The flow will form a vortex due to the shape of the section and the presence of the draft tube makes the lower side of the section have lower pressure. This vortex turbine has been designed to use a permanent magnet 150 watt AC generator. With a cross section of $60 \times 55 \times 150 \mathrm{~cm}$, draft tube $9.6 \mathrm{~mm}$ and $30 \times 50 \mathrm{~cm}$ turbine blade made of aluminum. In the framework used $3 \times$ $3.5 \mathrm{~cm}$ strip plate which is rolled. In order to withstand the impact of water on the blade, a shaft with an outer diameter of $22 \mathrm{~mm}$ and $16 \mathrm{~mm}$ of outer diameter is used with steel pipe material, and a nominal bearing life of 10274 hours. The resulting rotation is continued with a pulley with a diameter of $30 \mathrm{~mm}, 180 \mathrm{~mm}$ and with a belt type of $v$-belt material JIS K 6323 A 34 .
\end{abstract}

Keywords: electricity, generator, vortex, water turbine

\section{PENDAHULUAN}

\section{A. Latar Belakang}

Meningkatnya pertumbuhan penduduk di wilayah Indonesia akan sangat berpengaruh dengan tingginya kebutuhan energi khususnya energi listrik, kebutuhan energi listrik tiap tahun selalu mengalami peningkatan. Tidak hanya pada sektor rumah tangga saja, dampak perkembangan teknologi, informasi, dan sektor industri juga menjadi faktor meningkatnya kebutuhan energi lstrik. Potensi air sebagai energi alternatif di Indonesia sangat besar, penggunaannya dapat dilakukan pada setiap daerah sehingga turbin air lebih diutamakan dibanding dengan turbin angin.

Seiring besarnya potensi energi dari tenaga air sebagai pembangkit listrik perlu dilakukan banyak penelitian agar bisa memaksimalkan potensi tersebut. Salah satu caranya dengan membuat PLTPH, karena cukup banyak daerah- daerah Indonesia yang berpotensi dimanfaatkan airnya untuk tenaga penggerak turbin agar menghasilkan energi, seperti pada saluran irigasi, bendungan, sungai dan air terjun dengan memanfaatkan tinggi dari jatuhnya air. Kebanyakan turbin air dibuat dengan memanfaatkan aliran yang deras dan jatuhan air besar. Oleh sebab itu aliran air yang tidak terlalu deras belum banyak yang dimanfaatkan dengan baik. Dengan itu hal tersebut menimbulkan sebuah gagasan untuk memanfaatkan aliran air pada sungai dengan mengubahnya menjadi aliran vortex atau pusaran [1].

Turbin vortex dapat menjadi alternatif untuk beralih dari penggunaan energi fosil, dengan pemanfaatan EBT untuk dapat menghasilkan energi lisrik. Besarnya energi yang dihasilkan tergantung ketersedian air serta bentuk turbin. Turbin bekerja dengan memanfaatkan air sungai yang masuk pada penampang terdapat sudu di dalamnya, 
penampang dibuat agar air sungai yang masuk berubah menjadi aliran vortex atau pusaran.

Sehingga penulis ingin membuat rancang bangun alat atau prototipe turbin air yang digunakan untuk menghasilkan energi listrik, dengan memanfaatkan aliran yang diubah menjadi vortex atau pusaran. Pada prosesnya, analisa kinerja pada turbin di prototipe ini akan dibahas oleh mahaiswa lain pada saat pengujian prototipenya.

\section{B. Tujuan Tujuan}

Penelitian ini bertujuan untuk membuat atau rancang bangun prototipe turbin air yang bekerja memanfaatkan aliran air pada sungai yang diubah menjadi aliran vortex dengan berdasar pada teori-teori perancangan yang ada.

\section{Rumusan Masalah}

Berdasarkan latar belakang di atas, maka yang menjadi rumusan masalah dari penelitian ini adalah bagaimana memanfaatkan aliran air pada sungai yang potensinya cukup besar untuk diubah menjadi sebuah energi kinetik dengan jalan menggerakan turbin air dengan aliran vortex atau pusaran.

\section{Batasan Masalah}

Untuk menghindari meluasnya permasalahan yang akan dibahas maka diperlukan batasan masalah, agar mudah dalam memahami permasalahan yang dibahas maka diperlukan batasan masalah, diantaranya yaitu:

1. Penulis tidak membahas dan memaparkan mengenai perhitungan pada berbagai kondisi pembebanan di turbin.

2. Penulis tidak membahas analisa gaya-gaya atau free body diagram yang terjadi pada setiap tumpuan di kerangka penopang penampang.

3. Penulis tidak tidak melakukan simulasi CFD (Computation Fluid Dynamics) dengan sofware.

\section{LANDASAN TEORI}

\section{A. Aliran Air}

Aliran air termasuk ke dalam kategori fluida cair, aliran air menjadi salah suatu energi alami yang terdapat di bumi. Sudah lama aliran digunakan berbagai macam hal, contoh aliran air digunakan menggerakan kincir pada suatu kolam atau tambak untuk mencukupi kebutuhan oksigen pada hewan air seperti ikan da udang. Oleh beberapa ilmuan sendiri aliran air dimanfaatkan untuk menghasilkan suatu energi, salah satunya energi listrik. Aliran air yang mengalir memiliki energi yang bisa digunakan untuk memutar roda turbin [2]. Contoh penggunaan aliran air ditunjukkan pada Gambar 1 .

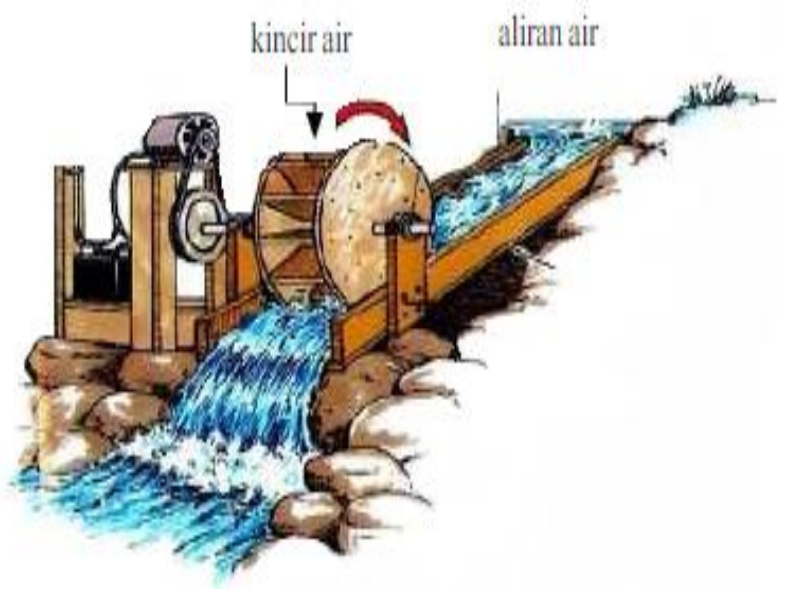

Gambar 1. Aliran air

Kaidah energi menyatakan suatu energi dapat diubah bentuk menjadi energi lain. Arus air yang mengandung energi dan energi tersebut dapat diubah bentuknya, misalnya perubahan dari energi potensial (tekanan) ke dalam energi kinetis (kecepatan), atau sebaliknya. Artinya kaidah kekekalan energi adalah apabila arus air dalam alirannya dilewatkan melalui turbin air, maka energi yang ada. Dalam air akan diubah menjadi bentuk energi yang lain [3].

\section{B. Mekanik Fluida}

Mekanika fluida adalah cabang dari mekanika terapan yang berkenaan dengan tingkah fluida dalam keadaan diam dan bergerak. Fluida merupakan zat yang mampu mengalir dan menyesuiakan bentuk dari wadahnya yang iya tempati [4]. Fluida dapat digolongkan cairan dan gas. Perbedaan utama pada keduanya yaitu:

1. Fluida cair bersifat inkompresibel sedangkan pada fluida merupakan gas bersifat kompresibel.

2. Fluida cair dapat mengisi volume tertentu, pada gas dengan massa tertentu akan mengembang sampai mengisi seluruh bagian wadahnya.

Pada aliran fluida sendiri terjadi beberapa aksi. Beberapa diantranya terdapat 3 jenis aliran, yaitu:

1. Aliran Laminar

Aliran dengan fluida bergerak di sepanjang lintasanlintasannya lurus dan tidak mengalami tumbukan atau saling bersilang antara satu dan lainnya. Bentuk aliran laminar ditunjukkan pada gambar 2 .

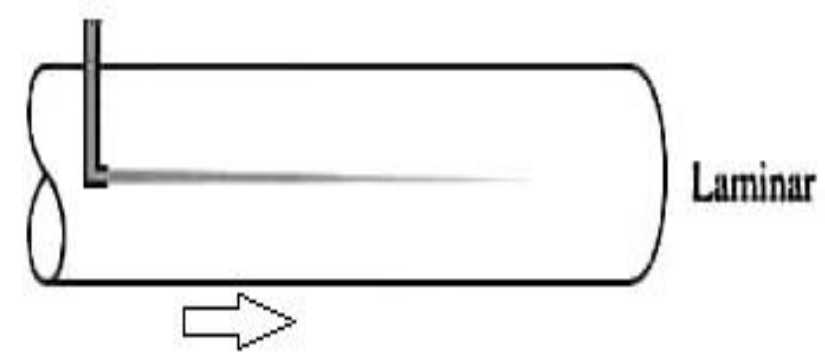

Gambar 2. Aliran laminar 


\section{Aliran Turbulen}

Aliran yang partikel fluidanya sangat tidak menentu pada pergerakannya, yang akibat aliran akan mengalami percampuran dan putaran partikel antar lapisan dan berakibat saling bertukar momentum dari satu bagian kebagian fluida lain dalam skala yang besar. Bentuk aliran turbulen ditunjukkan pada gambar 3 .

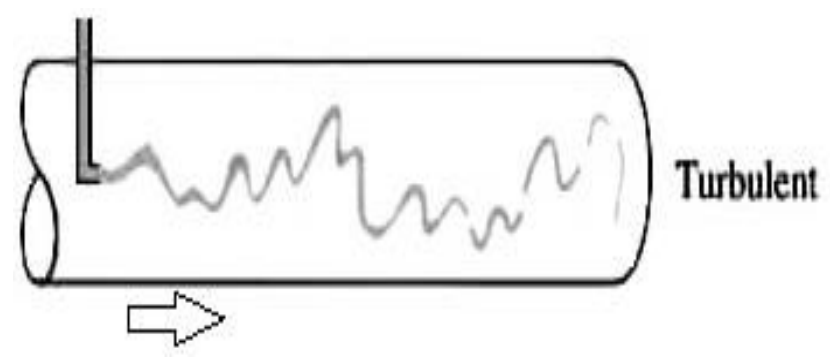

Gambar 3. Aliran turbulen

\section{Aliran Transisional}

Merupakan suatu aliran peralihan, dari aliran laminar menjadi aliran turbulen atau juga sebaliknya. Bentuk aliran transional ditunjukkan pada gambar 4.

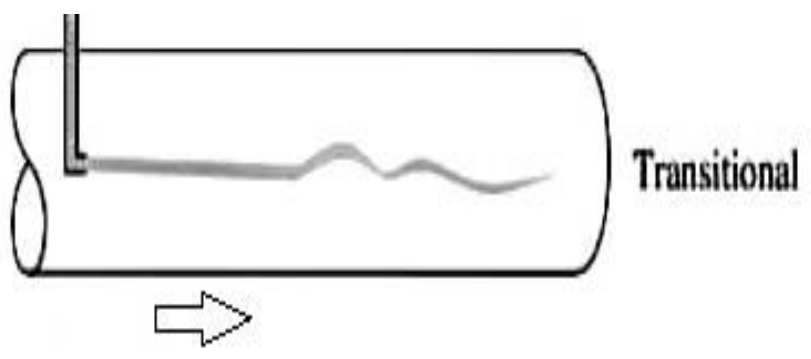

Gambar 4. Aliran transitional

\section{Turbin Impuls}

Turbin impuls bekerja dengan jalan mengubah energi potensial air menjadi energi kinetik pada nosel. Air yang keluar pada nosel memiliki tekanan dan kecepatan tinggi, kemudian langsung menumbuk sudu pada turbin. Terdapat beberapa jenis turbin implus, antara lain yaitu:

\section{Turbin Pelton}

Turbin pelton merupakan turbin yang terdiri dari satu set sudu jalan yang diputar oleh semprotan air pada nosel yang terdiri satu atau lebih nosel tersebut. Turbin pelton merupakan salah satu jenis turbin air paling efisien. Turbin ini sangat cocok bila digunakan untuk head yang tinggi, turbin pelton ditunjukkan pada gambar 5 .

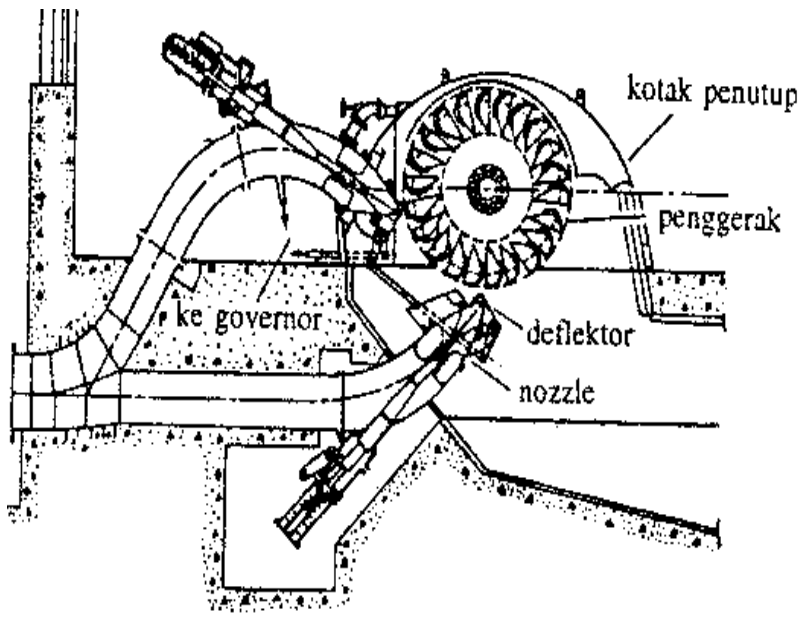

Gambar 5. Turbin pelton

\section{Turbin Turgo}

Turbin Turgo merupakan turbin impuls yang sering digunakan pada PLTMH dengan tinggi jatuh (head) yang tinggi karena bentuk kelengkungan sudu yang tajam. Turbin Turgo dikembangkan pada tahun 1919 oleh Gilkes sebagai modifikasi Turbin Pelton. Perbedaan utama turbin pelton dan turbin turgo yaitu bentuk sudunya, sudu turbin turgo berbentuk setengah dari bentuk sudu turbin pelton tetapi dengan jumlah dan ukuran sudu yang sama. Bentuk turbin turgo ditunjukkan pada Gambar 6.
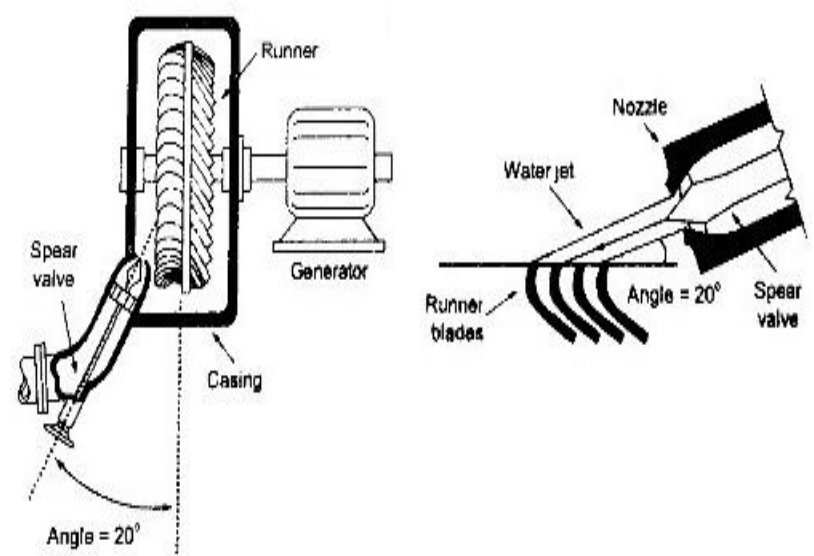

Gambar 6. Turbin turgo

\section{Turbin Crossflow}

Turbin crossflow merupakan turbin impuls dengan aliran radial, dapat dioperasikan pada debit air sebesar 20 liter/dt hingga 10.000 liter/dt dan head antara $1 \mathrm{~m}$ sampai $200 \mathrm{~m}$. Nosel persegi panjang dengan lebarnya yang sesuai dengan lebar runner untuk digunakan pada turbin ini. Semprotan air yang masuk ke turbin mengenai sudu sehingga terjadi konversi energi kinetik menjadi energi mekanik. Bentuk crossflow ditunjukkan pada Gambar 7. 


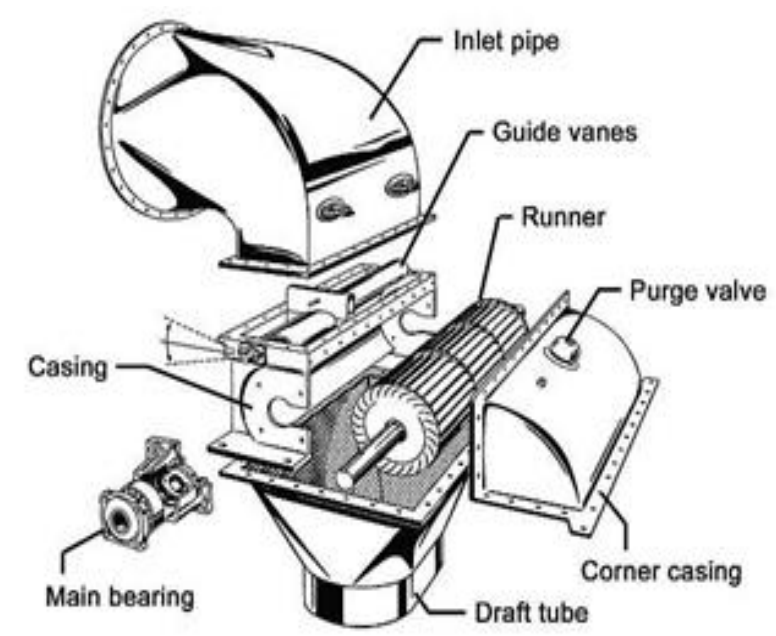

Gambar 7. Turbin crossflow

\section{Turbin Reaksi}

Turbin reaksi bekerja dengan cara merubah seluruh energi air yang tersedia menjadi suatu energi kinetik. Turbin ini merupakan turbin yang paling banyak diaplikasikan. Sudusudu yang ada pada turbin reaksi memiliki profil khusus sehingga terjadinya penurunan tekanan air selama melalui sudu. Perbedaan tekanan tersebut memberikan gaya pada sudu sehingga akhirnya runner dapat berputar. Untuk itu, turbin yang bekerja berdasarkan prinsip ini dikelompokkan seperti berikut:

\section{Turbin Francis}

Turbin dengan menggunakan sudu pengarah, sudu pengarah yang akan mengarahkan air masuk secara tangensial. Sudu pada turbin francis tersebut bisa berupa suatu sudu pengarah yang sudutnya tetap ataupun sudu pengarah yang dapat diatur sudutnya. Bentuk dari turbin ini ditunjukkan pada gambar 8 .

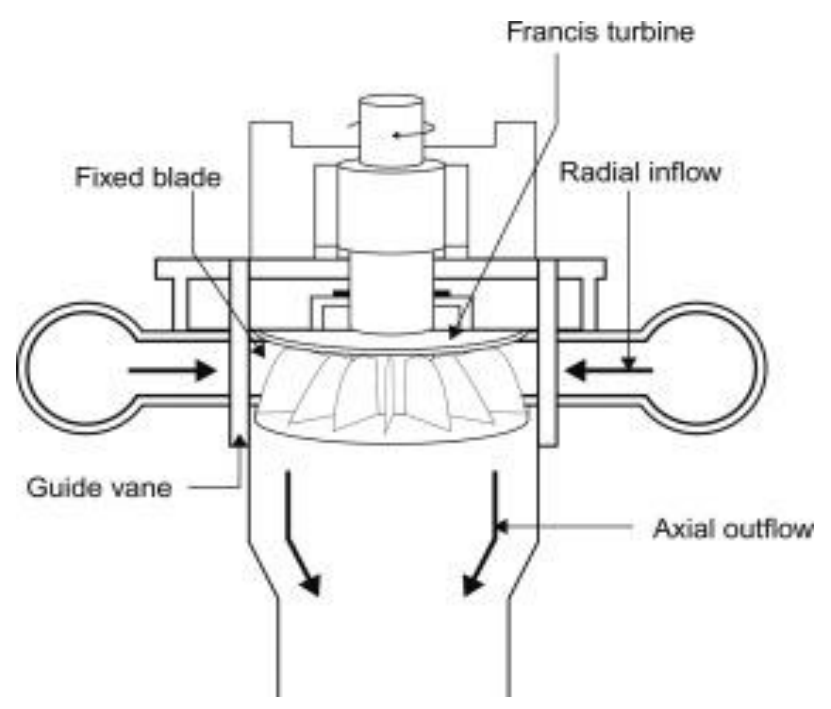

Gambar 8. Turbin francis

\section{Turbin Kaplan}

Turbin Kaplan cara kerjanya menggunakan prinsip reaksi. Turbin ini mempunyai roda jalan yang mirip dengan balingbaling pesawat terbang, seperti ditunjukkan pada Gambar 9. Bila baling-baling pesawat terbang berfungsi untuk menghasilkan gaya dorong, roda jalan pada turbin kaplan untuk menghasilkan energi kinetik.

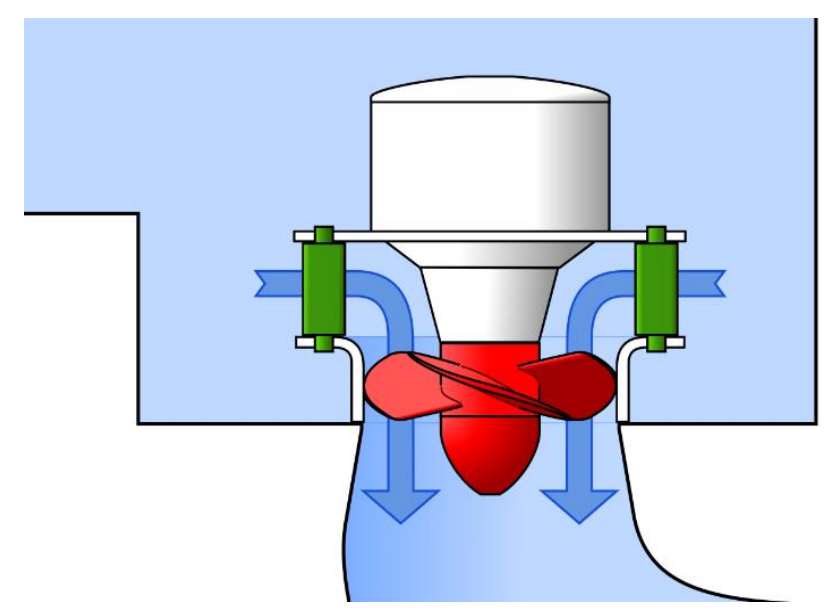

Gambar 9. Turbin kaplan

\section{Turbin Vortex}

Turbin ini dinamakan Gravitation Water Vortex Power Plant oleh penemunya Frans Zotleterer berkebangsaan Austria, tetapi turbin ini dikenal dengan turbin vortex. Sesuai dengan namanya, turbin ini memanfaatkan pusaran air buatan untuk memutar sudu turbin, kemudian diubah menjadi energi putaran pada poros.

Akibat saluran buang maka air akan membentuk aliran pusaran air. Ketinggian air (head) yang diperlukan untuk turbin ini 0,7-2 m dan debit berkisar 1000 liter per detik. Turbin ini sederhana, mudah dalam perawatannya, kecil, kuat, dan bertahan hingga 50-100 tahun. Turbin vortex ditunjukkan pada gambar 10 .

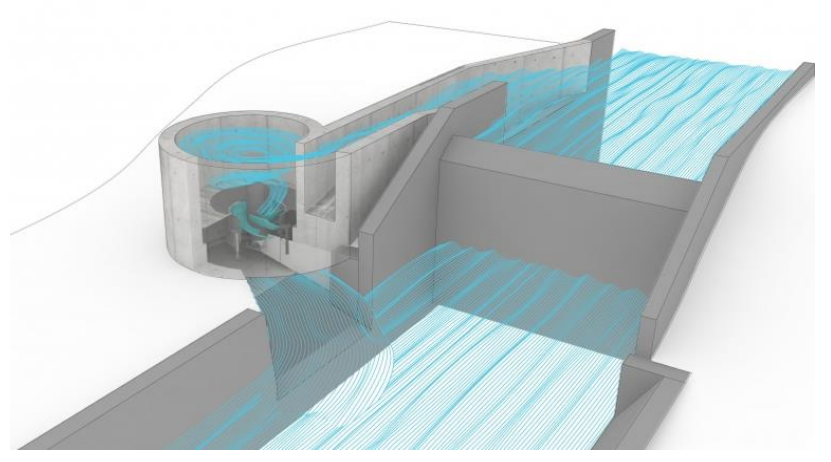

Gambar 10. Turbin vortex

\section{E. Cara Kerja Turbin Vortex}

Sistem pembangkit listrik dengan menggunakan pusaran air merupakan model turbin yang memanfaatkan energi yang terdapat pada pusaran air yang menciptakan pusarannya cara membuat perbedaan ukuran ketinggian 
head pada suatu aliran. Turbin ini dapat bekerja dengan tahapan-tahapn sebagai berikut:

1. Awalnya air dari sungai yang diberi sekat disalurkan menuju penampang atau tangki yang memiliki sirkulasi suatu lubang berbentuk lingkaran pada bagian dasarnya.

2. Air yang masuk arahnya mengikuti bentuk penampang yang dibuat dan tekanan rendah pada lubang membuat aliran keluar, sehingga pada penampang terbentuk aliran vortex.

3. Energi potensial yang terjadi diubah menjadi energi kinetik berupa rotasi pada pusat vortex dengan memberi turbin.

4. Air yang telah keluar melalui lubang sirkulasi tadi kemudian kembali lagi menuju sungai.

\section{F. Klasifikasi Vortex}

Dalam klasifikasi ada tiga tipe kekuatan vortex dengan melihat bentuk pusaran air ditunjukkan pada gambar 11 berikut ini.
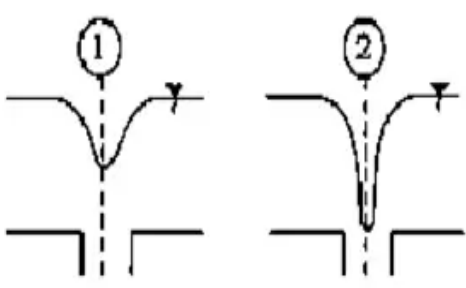

weak

undeveloped

combinęd potential

and rotational wortex (Rankine vartex)

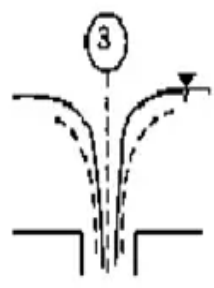

strong

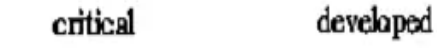

\section{critical stage potential wortex or for air-entrainment spiral vọrtex}

Gambar 11. Klasifikasi vortex berdasarkan kekuatannya

Secara umum, fenomena vortex terbagi atas dua bagian yaitu:

1. Vortex paksa

Adalah vortex yang terbentuk karena adanya gaya luar yang berpengaruh pada fluida.

2. Vortex bebas

Adalah vortex yang terbentuk karena fenomena natural, tidak terpengaruh oleh gaya dari luar sistem fluida, pada aliran inkompresibel, umumnya terjadi karena adanya lubang keluar.

Berikut adalah penemuan fundamental dari penilitian dari Institute of Technology, Sligo in Civil Engineering:

1. Bentuk permukan pusaran air dapat digambar secara matematik dan diprediksi secara akurat.

2. Efisiensi daya Pusaran air yang maksimal terjadi dalam jangkauan rasio antara diamater lubang dan diameter tangki adalah sekitar 14\%-18\% masing-masing untuk tempat head rendah dan tinggi.

3. Pusaran bervariasi secara linier sesuai dengan debit.

4. Energi keluar maksimum secera teoritis idealnya = pgQHv ( $\mathrm{Hv}=$ Height of Vortex $)$.

Efesiensi hidrolik maksimum meningkat saat kecepatan impeler setengah dari kecepatan fluida. Gambar 12 menunjukkan bentuk pusaran air secara matematis.

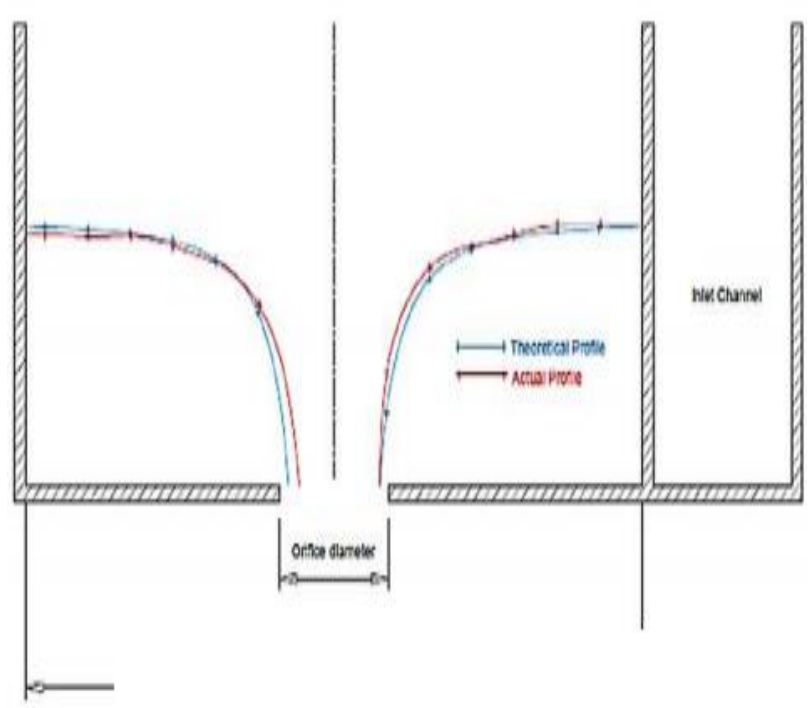

Gambar 12. Pusaran air secara matematis

\section{G. Saluran Masuk (inlet area)}

Ada beberapa tipe saluran masuk (inlet area), yaitu saluran masuk tipe involute, saluran masuk tipe ramp dan saluran masuk scroll. Berbagai tipe tersebut dimaksudkan untuk lebih memaksimalkan kinerja dari turbin. Dengan konstruksi lubang masuk dengan tipe involute, saluran masuk tipe ramp dan saluran masuk tipe scroll dapat mengurangi efek turbulensi yang terjadi disekitar dinding saluran masuk dan daerah antara saluran masuk ditunjukkan pada gambar 13 .

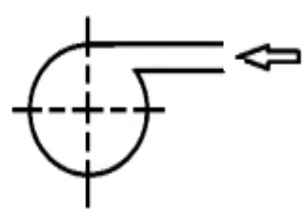

[A] OUTER WALL TANGENTIAL

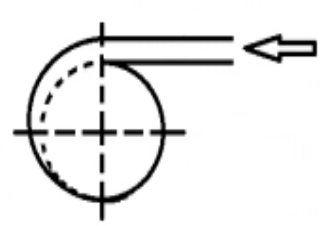

[C] RAMPED ENTRY OR SCROLLED EVOLUTIE

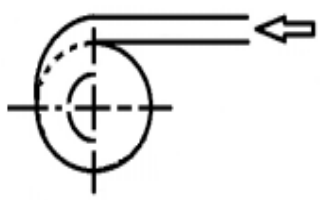

[B] INVOLUTE

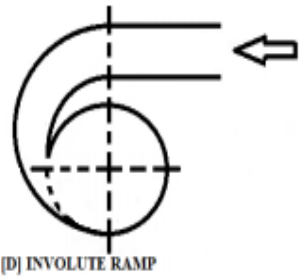

Gambar 13. Tipe lubang masuk turbin vortex

\section{H. Klasifikasi Generator}

Generator merupakan perangkat yang berfungsi untuk mengubah energi mekanik yang diperoleh dari sumber lain 
menjadi suatu energi listrik sebagai outputnya. Generator sendiri tidak menciptakan energi listrik, sebagai gantinya generator menggunakan energi mekanis yang diperoleh untuk mengerakan muatan listrik yang ada pada kawat gulungan melalui sirkuit listrik eksternal. Sumber energi gerak dari generator bermacam-macam. Misalnya, pembangkit tenaga air yang memanfaatkan aliran air untuk menggerakan kincir sehingga bisa berputar.

\section{Generator AC (alternating current)}

Seperti dengan namanya, generator AC menghasilkan arus bolak-balik antara cincin dan kutub magnetnya, sehingga menghasilkan voltase cukup untuk dialirkan ke luar generator. Pada generator AC cara kerjanya sangat berhubungan dengan konstruksi mesinnya. Kedua cinicin yang terdapat pada generator masing-masing terhubung dengan sikat karbon. Sikat karbon ini berfungsi untuk menyimpan arus listrik yang terjadi saat kumparan berputar antara kedua cincin. Seperti ditunjukkan pada gambar 14.

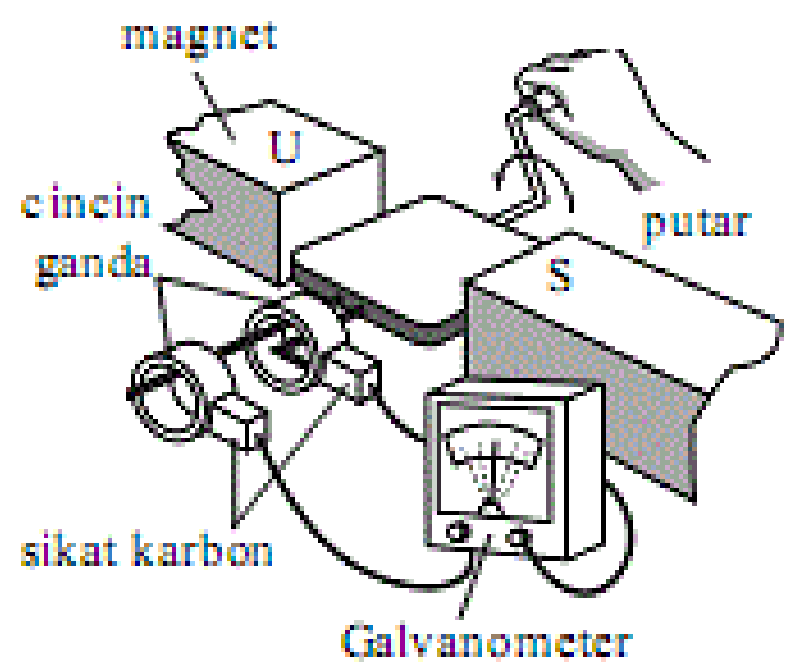

Gambar 14. Generator AC

\section{Generator DC (direct current)}

Generator DC merupakan suatu perangkat mesin listrik dinamis yang berfungsi untuk mengubah energi mekanis dalam bentuk gerak rotasi menjadi suatu energi listrik. Generator DC akan menghasilkan arus searah. Sistem kerja dari generator DC ditunjukkan pada gambar 15.

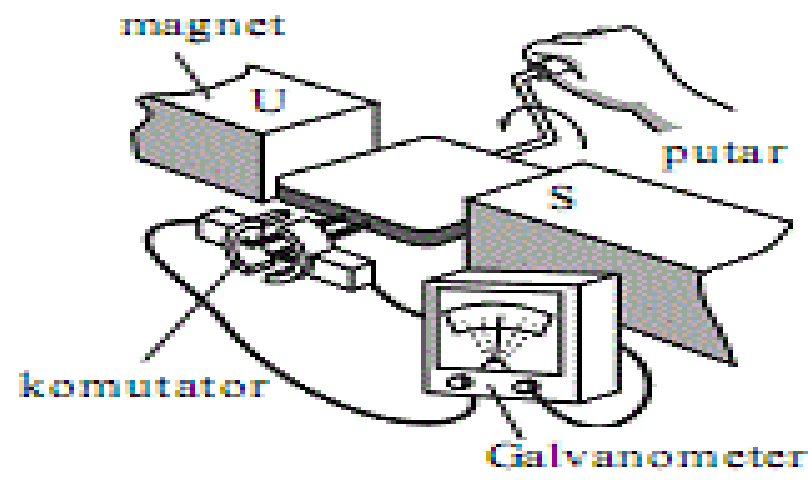

Gambar 15. Generator DC
Generator dengan sistem konvensional pada dasarnya menghasilkan arus bolak-balik. Untuk mengubah menjadi arus searah maka diperlukan suatu sistem yang diantaranya yaitu:

1. Sistem eksitasi dengan sikat (brush)

Sistem yang memakai suatu komutator dan sikat (brush) untuk mengubah arus AC dihasilkan menjadi DC. Komutator merupakan suatu alat berupa cincin belah.

2. Sistem eksitasi tanpa sikat (brushless)

Menggunakan rangkaian penyearah berupa empat dioda yang saling dihubungkan dengan arah yang berbeda untuk mengubah arus AC menjadi arus DC, seperti ditunjukkan pada gambar 16 .

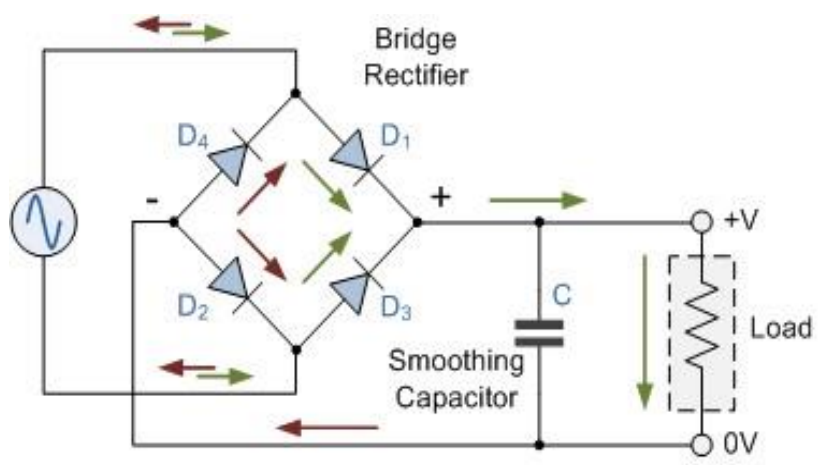

Gambar 16. Rangkaian penyearah

\section{J. Perancangan pada poros}

Poros merupakan elemen mesin yang berputar, digunakan untuk mentransmisikan daya dari suatu tempat ke tempat lain. Daya yang ditransmisikan poros dihasilkan dari beberapa gaya tangensial dan torsi (momen puntir). Untuk mentransfer daya dari satu poros ke poros lainnya dibutuhkan komponen pendukung seperti puli, roda gigi, dan lain-lain. Gambar .17 adalah contoh bentuk dari poros.

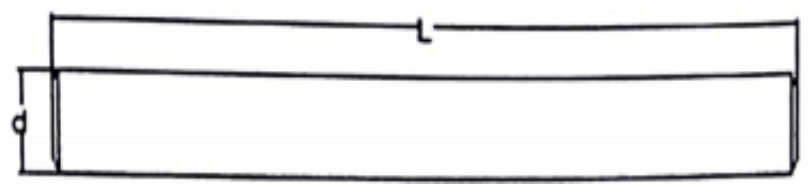

Gambar 17. Poros

Dalam perencanaan poros, pada bahan poros harus diperhitungkan. Material poros yang digunakan untuk turbin vortex ini yaitu S30C standar JIS G 4501, dengan karakteristik safety factor digunakan untuk perancangan poros berongga.

Untuk bisa memilih diantara empat safety factor yang ada, maka perlu diketahui terlebih dulu alasan dalam penggunaannya. Berikut keterangan untuk safety factor A, B, C, D, dan E:

$\mathrm{A}=\mathrm{vg}$, karena poros merupakan salah satu komponen terpenting

$\mathrm{B}=\mathrm{g}$, karena poros hanya menerima beban yang konstan.

$\mathrm{C}=\mathrm{g}$, perhitungan akurat dalam merancang poros. Tetapi banyak variable tidak diketahui sehingga banyak menggunakan asumsi.

$\mathrm{D}=\mathrm{vs}$, karena tidak ada factor yang membahayakan bagi pengguna.

$\mathrm{E}=\mathrm{ns}$, karena tidak ada perkara hukum. 


\section{K. Bantalan (bearing)}

Bantalan merupakan elemen mesin berfungsi menumpu poros, sehingga gesekan bolak dapat berlangsung secara halus dan aman. Bantalan harus tangguh memungkinkan poros serta elemen mesin lainnya bekerja dengan baik. Jika bantalan tidak berfungsi dengan baik maka prestasi seluruh sistem akan menurun atau tidak bekerja secara semestinya. Contoh bantalan ada pada Gambar 18 seperti berikut ini.

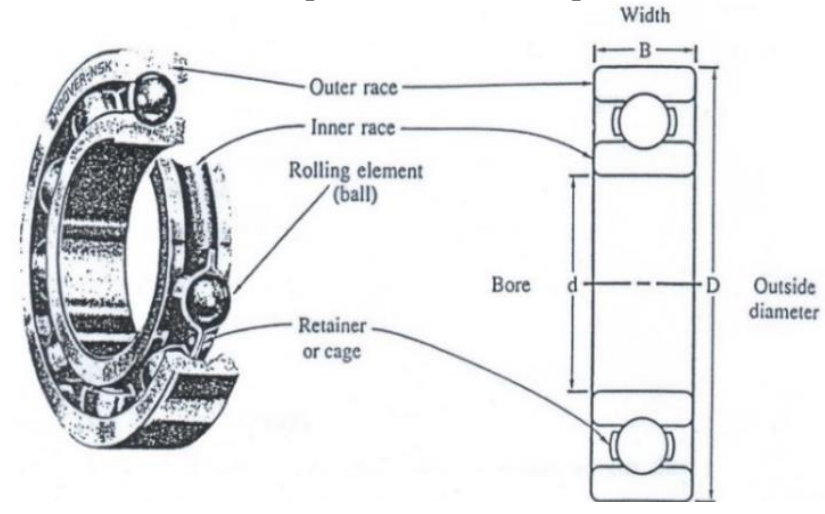

Gambar 18. Bantalan

\section{METODE EKSPERIMEN}

Pada penulisan penelitian menggunakan tiga metode yaitu studi literatur, perhitungan secara manual dan desain dengan software engineering. Pada studi literatur dilakukan dengan mencari referensi yang serupa dengan topik penelitian yang sedang dijalankan dari berbagai sumber seperti jurnal, skripsi, buku serta website. Setelah mengumpulkan data dengan metode studi literatur, kemudian dilanjutkan menghitung komponen pada permesinan dengan menggunakan persamaan-persamaan yang sesuai dengan topik penelitian. Langkah akhir adalah hasil perhitungan dikonversikan menjadi dimensi untuk keperluan desain dengan software engineering agar terbentuk tampilan 3D serta gambar kerja (drawing).

Pelaksanaan penelitian ini mengikuti diagram alir penelitian yang ditunjukkan pada gambar 19 .

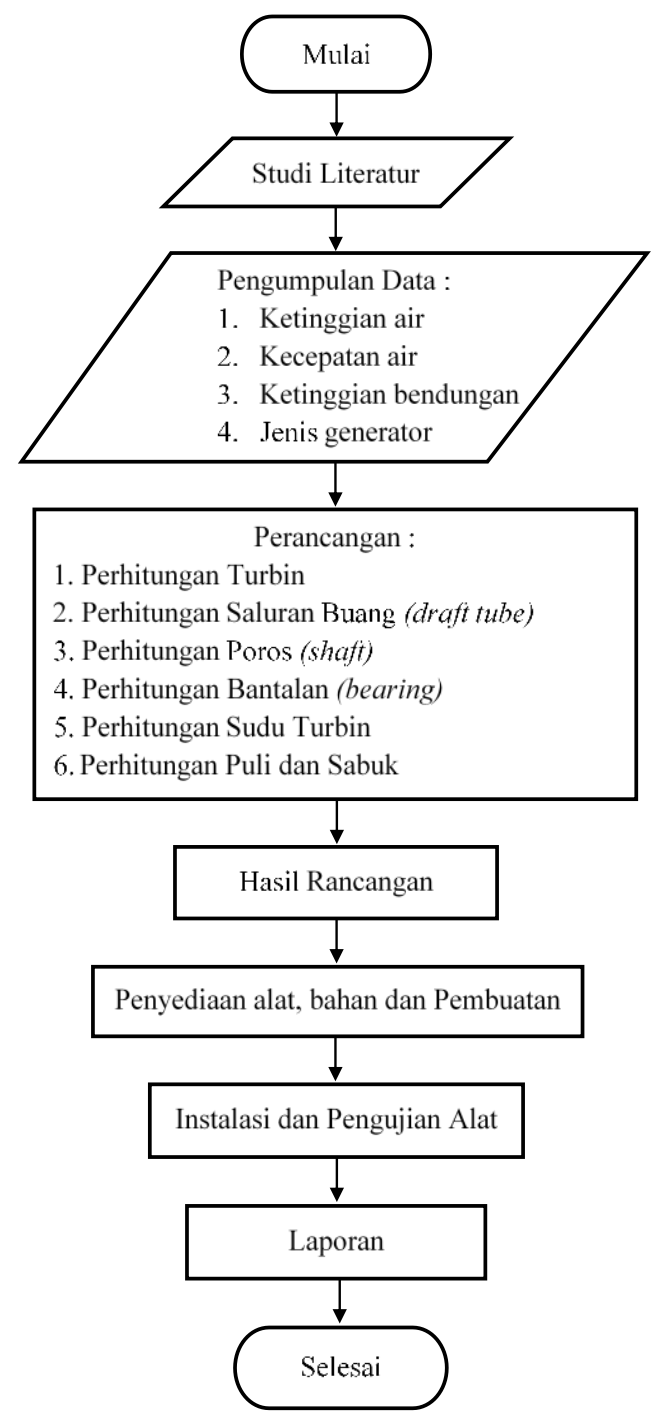

Gambar 19. Diagram alir penelitian

\section{HASIL DAN PEMBAHASAN}

A. Spesifikasi peralatan yang dirancang

Pada dasarnya, untuk merancang turbin air vortex membutuhkan berbagai sumber informasi dan spesifikasi pendukung agar desain sesuai kapasitas direncanakan. Didapat spesifikasi turbin air vortex yang akan dirancang yaitu:
1. Kapasitas generator
$=150$ watt
2. Kecepatan aliran
$=1,3 \mathrm{~m} / \mathrm{s}$
3. Putaran Generator
$=450 \mathrm{rpm}$
4. Jenis Penampang Turbin = involute

\section{B. Perhitungan penampang}

Penampang dibuat dengan tinggi $550 \mathrm{~mm}, \varnothing 600 \mathrm{~mm}$, panjang saluran masuk $900 \mathrm{~mm}$ dengan bentuk persegi berukuran $250 \mathrm{~mm}$. Dimensi penampang untuk lebih lengkapnya seperti ditunjukkanpada gambar 20. 


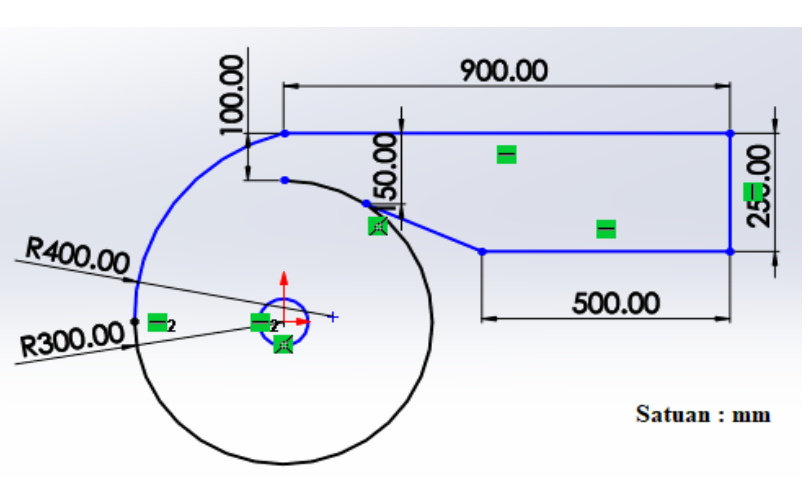

Gambar 20. Dimensi penampang

Luas Penampang $=\mathrm{X} . \mathrm{Y}$

$$
\begin{aligned}
& =0,25 \cdot 0,25 \\
& =0,00625 \mathrm{~m}^{2}
\end{aligned}
$$

\section{Debit Aliran Air Pada Penampang}

$$
\begin{aligned}
v & =\frac{Q}{A} \\
Q & =v \cdot A \\
& =1,3 \mathrm{~m} / \mathrm{s} \cdot 0,00625 \mathrm{~m}^{2} \\
& =0,00812 \mathrm{~m}^{3} / \mathrm{s}
\end{aligned}
$$

\section{Saluan Buang (Draft Tube)}

$$
\begin{aligned}
\text { Draft tube } & =D_{\text {tangki }} x(16 \%) \\
& =60 \mathrm{~cm} \times 16 \% \\
& =9,6 \mathrm{~cm}
\end{aligned}
$$

\section{E. Perancangan poros}

Perancangan poros merupakan perancangan yang digunakan untuk menentukan diamter poros serta kekuatan dari poros yang digunakan. Digunakan dengan jenis bahan S30C. untuk data-data perhitungan poros diantaranya yaitu :

- Faktor rasio $(\mathrm{k}) \quad=0,8$

- Faktor keamanan $=5$

- Daya yang digerakan $=150$ watt

Karena daya yang digunakan sudah dalam satuan watt, perhitungan bisa langsung dilakukan tanpa dikonversikan dahulu.

1. Tegangan geser izin

$$
\begin{aligned}
\tau & =\frac{\tau_{u}}{F s} \\
& =\frac{470,71}{5} \\
& =94,14 \mathrm{~N} / \mathrm{mm}^{2}
\end{aligned}
$$

2. Torsi yang ditransmisikan poros

$$
\begin{aligned}
T & =\frac{F \times 60}{2 \pi N} \\
T & =\frac{150 \times 60}{2 \pi 100} \\
T & =14,32=14,23 \times 10^{3} \text { N. mm }
\end{aligned}
$$

3. Diameter poros berongga

$$
\begin{aligned}
14,32 \times 10^{3} & =\frac{\pi}{16} \tau \cdot\left(d_{o}\right)^{3}\left(1-k^{4}\right) \\
14,32 \times 10^{3} & =\frac{\pi}{16} 94,14 \cdot\left(d_{o}\right)^{3}\left(1-(0,8)^{4}\right) \\
14,32 \times 10^{3} & =10,91 \cdot\left(d_{o}\right)^{3} \\
\left(d_{o}\right)^{3} & =\frac{14,32 \times 10^{3}}{10,91} \\
\left(d_{o}\right)^{3} & =1312,55 \\
d_{o} & =10,95 \approx 11 \mathrm{~mm}
\end{aligned}
$$

\section{F. Perancangan Bantalan}

Poros sudu diketahui berdiameter $20 \mathrm{~mm}$, sehingga pemilihan bearing dipilih dengan jenis gelinding dengan number 6004 , dan dari pemilihan tersebut didapat data-data sebagai berikut:

- $\mathrm{D}=42$

- $\mathrm{B}=12$

- $C_{0}=465 \mathrm{lb}$

- $\mathrm{C}=735 \mathrm{lb}$

1. Beban radial

Beban radial pada bantalan sebesar $2,5 \mathrm{~kg}$. Terdiri dari beban sudu dan poros $=2 \mathrm{~kg}$, beban tambahan $=0,5 \mathrm{~kg}$.

2. Faktor kecepatan

$$
\begin{aligned}
f_{n} & =\left(\frac{33,3}{n}\right)^{1 / 3} \\
& =\left(\frac{33,3}{n}\right)^{1 / 3}=0,69 \mathrm{rpm}
\end{aligned}
$$

3. Dinamis spesifik yang terjadi pada bantalan (C)

$$
\begin{aligned}
\mathrm{F}_{\mathrm{h}} & =\mathrm{F}_{\mathrm{n}} \times \frac{C}{P} \\
\mathrm{C} & =\frac{P \cdot F_{h}}{F_{n}} \\
& =\frac{2,55 \mathrm{~kg} \cdot 2,12}{0,69 \mathrm{rpm}} \\
& =7,83 \mathrm{~kg}
\end{aligned}
$$

Nilai dinamis spesifik yang terjadi pada bantalan sebesar $7,83 \mathrm{~kg}$, maka bantalan yang digunakan yaitu bantalan dengan nomor 6004.

\section{G. Perhitungan sudu turbin}

Pada sudu turbin masing-masing berukuran $130 \mathrm{~mm}$ yang membentuk lengkungan simetris dengan jari-jari $300 \mathrm{~mm}$ dan jarak antar sudu sebesar $60^{\circ}$. Sehingga, total dengan poros $\emptyset 20 \mathrm{~mm}$ maka diameter sudu keseluruhan yang digunakan yaitu $\emptyset 300 \mathrm{~mm}$. Utuk bentuk sudu dapat dilihat seperti ditunjukkan pada gambar 21 . 


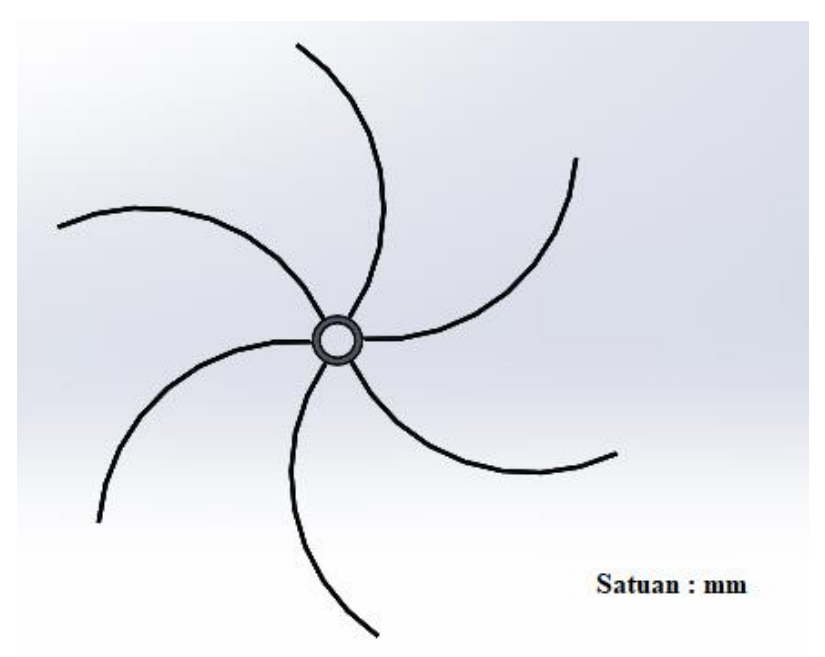

Gambar 21. Bentuk sudu turbin

1. Analisis segitiga kecepatan pada sisi masuk

Digunakan untuk mencari dan menentukan berapa nilai yang dihasilkan dari perhitungan kecepatan pada sisi keluar sudu turbin.

- Kecepatan absolut pada sisi masuk

$$
\begin{aligned}
V_{1} & =\frac{Q}{A} \\
V_{1} & =\frac{0,00812}{0,00625} \\
& =1,3 \mathrm{~m} / \mathrm{s}
\end{aligned}
$$

- Kecepatan sekeliling roda jalan

$$
\begin{aligned}
U_{1} & =\frac{V_{1}}{2} \\
& =\frac{1,3}{2} \\
& =0,65
\end{aligned}
$$

- Kecepatan relatif pada sisi masuk

$$
\begin{aligned}
V_{r 1} & =V_{1}-\mathrm{U} \\
& =1,3-0,65 \\
& =0,65 \mathrm{~m} / \mathrm{s}
\end{aligned}
$$

- Kecepatan air memutar roda jalan

$$
V_{w 1}=V_{1}=1,3 \mathrm{~m} / \mathrm{s}
$$

2. Analisis Segitiga Kecepatan Pada Sisi Keluar

Digunakan untuk mencari dan menentukan berapa nilai yang dihasilkan dari perhitungan kecepatan pada sisi masuk sudu turbin.

- Kecepatan relatif pada sisi keluar

$$
V_{r 2}=V_{r 1}=0,65 \mathrm{~m} / \mathrm{s}
$$

- Kecepatan sekeliling roda pada sisi keluar

$$
U_{2}=U_{1}=0,65 \mathrm{~m} / \mathrm{s}
$$

- Kecepatan air memutar roda pada sisi keluar

$$
\begin{aligned}
V_{w 2} & =V_{r 2} \cos \emptyset-U \\
& =0,65 \cos 60-0,65 \\
& =-0,32 \mathrm{~m} / \mathrm{s}
\end{aligned}
$$

- Kecepatan air keluar

$$
\begin{aligned}
V_{f 2} & =V_{2} \sin \emptyset \\
& =1,3 \cdot \sin 60 \\
& =1,12 \mathrm{~m} / \mathrm{s}
\end{aligned}
$$

Dari hasil perhitungan tersebut maka dapat digambar segitiga kecepatan pada sisi masuk dan keluar roda jalan seperti ditunjukkan pada gambar 22.

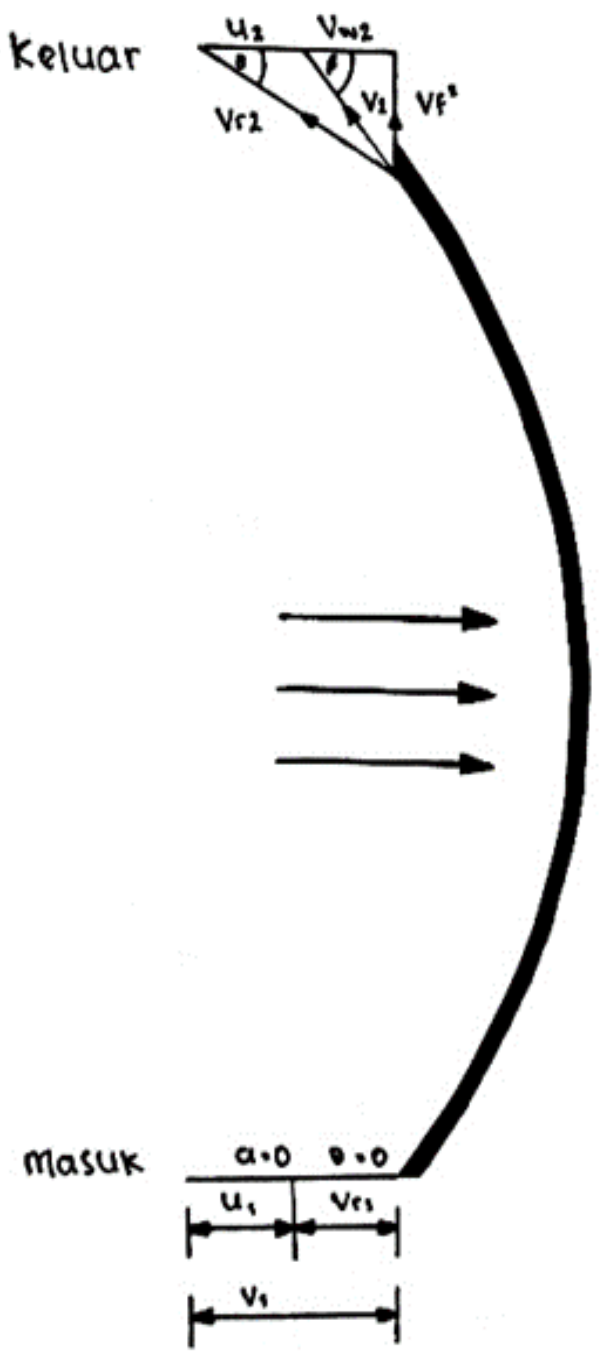

Gambar 22. Segitiga kecepatan sudu

\section{H. PERHITUNGAN PULI DAN SABUK}

Puli merupakan elemen mesin yang digunakan untuk meneruskan daya dari satu poros ke poros lain dengan menggunakan sabuk, berukut ini beberapa diantaranya yaitu. 1. Perbandingan Kecepatan

$$
\begin{aligned}
i=\frac{N_{2}}{N_{1}} & =\frac{d_{p}}{D_{p}} \\
\text { Maka: } i & =\frac{450 \mathrm{rpm}}{75 \mathrm{rpm}}=\frac{30 \mathrm{~mm}}{D_{p}} \\
\mathrm{Dp} & =\frac{450 \mathrm{rpm} .30 \mathrm{~mm}}{75 \mathrm{rpm}}=180 \mathrm{~mm}
\end{aligned}
$$


2. Kecepatan Linier Sabuk

- Kecepatan puli pada sudu turbin

$$
\begin{aligned}
v & =\frac{3,14 \cdot D_{p} \cdot N_{1}}{60 \cdot 1000} \\
& =\frac{3,14 \cdot 180 \mathrm{~mm} \cdot 75 \mathrm{rpm}}{60 \cdot 1000} \\
& =0,70 \mathrm{~m} / \mathrm{s}
\end{aligned}
$$

- Kecepatan puli generator

$$
\begin{aligned}
v & =\frac{3,14 \cdot d_{p} \cdot N_{2}}{60 \cdot 1000} \\
& =\frac{3,14 \cdot 30 \mathrm{~mm} \cdot 450 \mathrm{rpm}}{60 \cdot 1000} \\
& =0,70 \mathrm{~m} / \mathrm{s}
\end{aligned}
$$

3. Kecepatan Sudut Puli

- Kecepatan sudut puli sudu turbin

$$
\begin{aligned}
\omega & =\frac{v \cdot 1000}{D_{p}} \\
& =\frac{0,70 \mathrm{~m} / \mathrm{s} \cdot 1000}{180 \mathrm{~mm}} \\
& =3,8 \mathrm{rad} / \mathrm{s}
\end{aligned}
$$

- Kecepatan sudut puli generator

$$
\begin{aligned}
\omega & =\frac{v \cdot 1000}{d_{p}} \\
& =\frac{0,70 \mathrm{~m} / \mathrm{s} \cdot 1000}{30 \mathrm{~mm}} \\
& =23,3 \mathrm{rad} / \mathrm{s}
\end{aligned}
$$

\section{Panjang Sabuk}

Panjang total yang digunakan memutar puli, jarak antar poros $250 \mathrm{~mm}$. Dalam perancangan digunakan sabuk terbuka, persamaan panjang total sabuk dapat ditulis sebagai berikut.

$$
\begin{aligned}
& L=\frac{\pi}{2}\left(D_{p}+d_{p}\right)+2 x+\frac{\left(D_{p}-d_{p}\right)^{2}}{4 x} \\
& L=\frac{3,14}{2}(180 \mathrm{~mm}+30 \mathrm{~mm})+2.250 \mathrm{~mm}+\frac{(180 \mathrm{~mm}-30 \mathrm{~mm})^{2}}{4.250 \mathrm{~mm}} \\
& \mathrm{~L}=852,2 \mathrm{~mm} \approx 864 \mathrm{~mm} \approx 34 \mathrm{Inch}
\end{aligned}
$$

Oleh karena itu diputuskan menggunakan jenis sabuk V dengan material JIS K 6323 A 34.

\section{KESIMPULAN}

1. Bodi dan saluran masuk menggunakan model involute, dengan diameter $0,6 \mathrm{~m}$, inlet $0,00625 \mathrm{~m}^{2}$ dan panjang total turbin $1,2 \mathrm{~m}$.

2. Saluran buang (draft tube) digunakan berdiameter yaitu $9,6 \mathrm{~cm}$.

3. Poros sudu menggunakan bahan S30C, berdiameter 20 $\mathrm{mm}$ tebal $3 \mathrm{~mm}$ dan tinggi $70 \mathrm{~cm}$.

4. Digunakan bantalan radial dengan nomor 6004 , diameter dalam $20 \mathrm{~mm}$ dan diameter luar $42 \mathrm{~mm}$ serta tebal 12 $\mathrm{mm}$.
5. Puli jenis v-belt dengan diameter $30 \mathrm{~mm}$ untuk generator dan $180 \mathrm{~mm}$ untuk poros sudu.

6. Sabuk menggunakan jenis v-belt dengan panjang 864 mm dan material belt code JIS K 6323 A 34.

\section{REFERENSI}

[1] B. Baskoro, Uji eksperimental pengaruh sudut basin cone terhadap kinerja turbin reaksi aliran vortex, Jurnal Teknik Mesin, vol. 5, no. 1, 2017, pp. 2-4.

[2] Gatot, S. dan Supriyo, Pembuatan turbin vortex dengan sudu pipa belah tiga dengan sudut kemiringan sudu $45^{\circ}$, Jurnal Teknik Energi, vol. 14, no. 2, 2018, pp. 3-7.

[3] Khurmi, R.S. and J.K. Gupta. A text book of machine design, Eurasia Publishing House, Ram Nagar-New Delhi, 1982.

[4] Kurniawan, H. A., Pengaruh sudut inlet notch pada turbin reaksi aliran vortex terhadap daya dan efisiensi. Jurnal Teknik Mesin, vol. 5, no. 1, 2017, pp. 2.

[5] Maulana, D. W., F. M Rizwan., C. Mulyana., F. Faizal., C. Panatarani., \& I. M. Joni, Gravitational water vortex pico hydro power modeling for aquaculture implementation. Journal of Physics: Conference Series, vol. 15, 2016, pp. 4-5.

[6] Munson, B. M., Young, D. F., \& Okiishi, T. H., Mekanika fluida, Erlangga, 2003.

[7] Power, C., Aunghus, M. N., \& Paul, C., A parametric experimental investigation of the operating conditions of gravitational vortex hydro power, Journal of Clean Energy Tecnologies, vol. 2, 2016, pp. 112-119.

[8] Sena, A., Eksperimental pengaruh kemiringan sudut sudu berpenampang plat data terhadap kinerja turbin aliran vortex, Jurnal Teknik Mesin, vol. 50, no. 2, 2018, pp. 06.

[9] Sritram, P., W, Treedet., \& R. Suntivarakorn. Effect of turbine materials on power generation efficiency from free water vortex hydro power plant. Materials Science and Engineering, vol. 103, 2015, pp. 1-7.

[10] Suharyati, Sadmoko H. P., Jamaludin L. W., Nurina I. P. Outlook Energi Indonesia 2019, 2019.

[11] Sularso, \& Suga, K., Dasar perencanaan dan pemilihan elemen mesin, PT. AKA, 2004.

[12] Victor, L. Streeter., \& E. Benjamin, Wylie., Mekanika fluida, Erlangga, 1998. 